\title{
Promicromonospora xylanilytica sp. nov., an endophytic actinomycete isolated from surface- sterilized leaves of the medicinal plant Maytenus austroyunnanensis
}

\author{
Sheng Oin, ${ }^{1,2}$ Ji-Hong Jiang, ${ }^{2}$ Hans-Peter Klenk, ${ }^{3}$ Wen-Yong Zhu, ${ }^{1}$ \\ Guo-Zhen Zhao, ${ }^{1}$ Li-Xing Zhao, ${ }^{1}$ Shu-Kun Tang, ${ }^{1}$ Li-Hua Xu ${ }^{1}$ \\ and Wen-Jun $\mathrm{Li}^{1}$
}

Correspondence

Wen-Jun Li

wjli@ynu.edu.cn or

liact@hotmail.com

\author{
${ }^{1}$ Key Laboratory of Microbial Diversity in Southwest China, Ministry of Education, \\ and Laboratory for Conservation and Utilization of Bio-resources, \\ Yunnan Institute of Microbiology, Yunnan University, Kunming, Yunnan 650091, PR China \\ ${ }^{2}$ The Key Laboratory of Biotechnology for Medicinal Plant of Jiangsu Province, \\ Xuzhou Normal University, Xuzhou, Jiangsu 221116, PR China \\ ${ }^{3} \mathrm{DSMZ}$ - Deutsche Sammlung von Mikroorganismen und Zellkulturen GmbH, Inhoffenstraße 7b, \\ D-38124 Braunschweig, Germany
}

\begin{abstract}
A novel xylan-degrading actinomycete, strain YIM $61515^{\top}$, was isolated from surface-sterilized leaves of the medicinal plant Maytenus austroyunnanensis. Cells were Gram-positive and non-spore-forming, produced primary branches and formed white to yellowish white colonies on the media tested. Phylogenetic analysis based on 16S rRNA gene sequences showed that strain YIM $61515^{\top}$ was most similar to Promicromonospora aerolata V54A ${ }^{\top}$ and Promicromonospora vindobonensis $\mathrm{V}_{4} 5^{\top}$ (99.4 and $99.1 \%$ sequence similarity, respectively). The isolate formed a separate lineage in a cluster containing $P$. aerolata $V 54 A^{\top}$. 16S rRNA gene sequence similarity between the isolate and other members of the genus Promicromonospora ranged from 96.3 to $98.4 \%$. Chemotaxonomic data, including major menaquinones, fatty acid compositions and polar lipid profiles, supported the placement of strain YIM $61515^{\top}$ in the genus Promicromonospora. DNA-DNA relatedness, physiological and biochemical data showed that strain YIM $61515^{\top}$ could be distinguished from members of all known species of the genus Promicromonospora and therefore represented a novel species. The name Promicromonospora xylanilytica sp. nov. is proposed, with YIM $61515^{\top}\left(=\mathrm{DSM} 21603^{\top}=\right.$ CCTCC AA $\left.208046^{\top}\right)$ as type strain.
\end{abstract}

The genus Promicromonospora was proposed by Krasil'nikov et al. (1961) as a member of the family Promicromonosporaceae. Members of the genus are aerobic, Gram-positive, non-spore-forming actinomycetes, which form an extensively branched substrate mycelium that fragments into bacillary or coccoid elements. At the time of writing, the genus Promicromonospora comprised seven species with validly published names: Promicromonospora citrea (Krasil'nikov et al., 1961), P. sukumoe (Takahashi et al., 1987), P. aerolata and $P$. vindobonensis (Busse et al., 2003), P. kroppenstedtii (Alonso-Vega et al., 2008), P. flava (Jiang et al., 2009) and $P$. umidemergens (Martin et al., 2010), isolated from soil, air,

Abbreviation: ISP, International Streptomyces Project.

The GenBank/EMBL/DDBJ accession number for the 16S rRNA gene sequence of strain YIM $61515^{\top}$ is FJ214352.

A supplementary table and two supplementary figures are available with the online version of this paper. sediment and moisture from indoor wall material. During a study of rare actinobacteria associated with the tropical rainforest medicinal plants of Xishuangbanna, Yunnan Province, south-west China and the screening of actinomycetes that degrade plant polymers, a Promicromonosporalike strain, designated YIM $61515^{\mathrm{T}}$, was isolated from healthy leaves of a traditional Chinese medicinal plant, Maytenus austroyunnanensis. This is the first endophytic actinomycete identified as a member of the genus Promicromonospora.

Strain YIM $61515^{\mathrm{T}}$ was isolated from healthy leaf samples as follows. Samples were air dried for $48 \mathrm{~h}$ at room temperature and then washed ultrasonically $(160 \mathrm{~W}$, $15 \mathrm{~min}$ ) to completely remove surface soil and adherent epiphytes. After drying, the samples were subjected to a five-step surface-sterilization procedure, described by Qin et al. (2008). After being thoroughly dried under sterile conditions, the samples were heated for $15 \mathrm{~min}$ at $100{ }^{\circ} \mathrm{C}$ 
and pretreated by the combined enzymic hydrolysis and differential centrifugation method of Qin et al. (2009). Strain YIM $61515^{\mathrm{T}}$ was isolated after incubation at $28{ }^{\circ} \mathrm{C}$ for 2 weeks on xylan-arginine agar [per litre: $2.5 \mathrm{~g}$ xylan, $1.0 \mathrm{~g}$ arginine, $1.0 \mathrm{~g}\left(\mathrm{NH}_{4}\right)_{2} \mathrm{SO}_{4}, 2.0 \mathrm{~g} \mathrm{CaCl}_{2}, 1.0 \mathrm{~g} \mathrm{~K}_{2} \mathrm{HPO}_{4}, 0.2 \mathrm{~g}$ $\mathrm{MgSO}_{4} \cdot 7 \mathrm{H}_{2} \mathrm{O}, 10 \mathrm{mg} \mathrm{FeSO}$. $7 \mathrm{H}_{2} \mathrm{O}, 15.0 \mathrm{~g}$ agar; $\mathrm{pH}$ 7.2]. The isolate was maintained as mycelial fragments suspended in $20 \%(\mathrm{v} / \mathrm{v})$ glycerol at $-80{ }^{\circ} \mathrm{C}$.

The morphological and cultural characteristics were observed on yeast extract-malt extract agar (International Streptomyces Project medium 2; ISP 2), oatmeal agar (ISP 3), inorganic salts-starch agar (ISP 4) and glycerol-asparagine agar (ISP 5) (Shirling \& Gottlieb, 1966), as well as potatoglucose agar (Difco), Czapek's agar and nutrient agar (Waksman, 1967) for 3 weeks at $28{ }^{\circ} \mathrm{C}$. Colours were determined according to Kelly (1964). The mycelium was observed by light microscopy (BH-2; Olympus) and scanning electron microscopy (JSM 5600LV; JEOL). Growth at $\mathrm{pH} 4.0-11.0$ (at intervals of $0.5 \mathrm{pH}$ units) and at $0,4,7$, $10,12,15,18,20,22,25,28,30,32,35,37,40,45,50,55$ and $60{ }^{\circ} \mathrm{C}$ was tested on ISP 2 . Growth with $0-20 \%(w / v) \mathrm{NaCl}$ (at intervals of $0.5 \%$ ) was tested on ISP 2. Growth was assessed after incubation for 14 days at $28{ }^{\circ} \mathrm{C}$. Strain YIM $61515^{\mathrm{T}}$ was examined for a range of phenotypic properties using standard procedures (Gordon et al., 1974) and the API Coryne, API ZYM and API 50CH systems (bioMérieux), according to the manufacturer's instructions. $P$. aerolata $\mathrm{V} 54 \mathrm{~A}^{\mathrm{T}}$ and $P$. vindobonensis $\mathrm{V} 45^{\mathrm{T}}$ were used as reference strains under the same conditions.

Strain YIM $61515^{\mathrm{T}}$ was an aerobic, Gram-positive, nonspore-forming actinomycete. It grew well on ISP $2-5$ and nutrient agar and moderately well on potato-glucose agar and Czapek's media. No diffusible pigments or aerial mycelium were produced. The substrate mycelium was well developed and fragmented into non-motile, coccoid, Y-shaped, Vshaped or curved bacillary elements (Supplementary Fig. S1, available in IJSEM Online). Colonies were white to yellowish white and the substrate mycelium was white or yellowish white to orange-yellow. The physiological and biochemical properties of strain YIM $61515^{\mathrm{T}}$ are given in Table 1 and the species description.

Cell walls were purified and the amino acids of the peptidoglycan were analysed by TLC (Lechevalier \& Lechevalier, 1980; Jiang et al., 2001). Sugar analysis of whole-cell hydrolysates was performed according to the procedure described by Hasegawa et al. (1983). Menaquinones were prepared and analysed by HPLC (Groth et al., 1997). Polar lipids were extracted, examined using twodimensional TLC and identified using published procedures (Minnikin et al., 1979; Collins \& Jones, 1980). Biomass for quantitative fatty acid analysis was prepared by scraping colonies from tryptic soy agar after incubation for 2 days at $28{ }^{\circ} \mathrm{C}$. The fatty acids were extracted and prepared according to the standard protocol of the MIDI/Hewlett Packard Microbial Identification system. The fatty acid methyl esters were analysed by using Microbial Identification software
Table 1. Differential phenotypic characteristics of strain YIM $61515^{\top}$ and closely related type strains of species of the genus Promicromonospora

Strains: 1, Promicromonospora xylanilytica sp. nov. YIM $61515^{\mathrm{T}} ; 2, P$. vindobonensis $\mathrm{V}^{2} 5^{\mathrm{T}} ; 3$, P. aerolata $\mathrm{V} 54 \mathrm{~A}^{\mathrm{T}} ; 4$, P. kroppenstedtii $\mathrm{RS}_{16}{ }^{\mathrm{T}}$; 5, P. umidemergens $09-\mathrm{Be}-007^{\mathrm{T}} ; 6, P$. sukumoe DSM $44121^{\mathrm{T}} ; 7, P$. citrea DSM $43110^{\mathrm{T}}$. Data for columns 1-3 were taken from this study and for columns 4-7 from Martin et al. (2010) and Alonso-Vega et al. (2008). +, Positive; w, weakly positive; -, negative; ND, no data available.

\begin{tabular}{|c|c|c|c|c|c|c|c|}
\hline Characteristic & 1 & 2 & 3 & 4 & 5 & 6 & 7 \\
\hline $\begin{array}{l}\text { Colony colour on } \\
\text { ISP } 2^{*}\end{array}$ & WH/YW & $\mathrm{WH} / \mathrm{C}$ & $\mathrm{WH} / \mathrm{C}$ & C/LY & $\mathrm{ND}$ & $\mathrm{Y}$ & LY \\
\hline Oxidase & + & + & + & + & ND & - & - \\
\hline Nitrate reduction & + & + & + & + & $\mathrm{ND}$ & - & + \\
\hline \multicolumn{8}{|l|}{ Hydrolysis of: } \\
\hline Gelatin & - & - & $\mathrm{W}$ & + & ND & + & + \\
\hline Xylan & + & - & + & + & $\mathrm{ND}$ & - & + \\
\hline \multicolumn{8}{|c|}{ Enzymes (API ZYM) } \\
\hline $\begin{array}{l}\text { Acid } \\
\text { phosphatase }\end{array}$ & + & + & - & + & ND & + & + \\
\hline$\alpha$-Chymotrypsin & - & - & $\mathrm{W}$ & - & ND & - & - \\
\hline Trypsin & - & $\mathrm{W}$ & $\mathrm{W}$ & $\mathrm{W}$ & ND & + & + \\
\hline \multicolumn{8}{|c|}{ Assimilation (API $50 \mathrm{CH}$ ) } \\
\hline Adonitol & - & - & + & - & $\mathrm{ND}$ & - & - \\
\hline D-Fructose & $\mathrm{w}$ & $\mathrm{W}$ & + & - & + & + & + \\
\hline Galactose & - & $\mathrm{W}$ & $\mathrm{W}$ & - & ND & + & + \\
\hline D-Glucose & + & + & $\mathrm{w}$ & + & + & + & + \\
\hline Glycerol & + & + & + & $\mathrm{W}$ & $\mathrm{ND}$ & + & + \\
\hline Inulin & - & + & - & - & $\mathrm{ND}$ & - & + \\
\hline 2-Ketogluconate & - & $\mathrm{W}$ & + & + & $\mathrm{ND}$ & $\mathrm{w}$ & + \\
\hline 5-Ketogluconate & - & + & + & + & ND & $\mathrm{w}$ & + \\
\hline Lactose & $\mathrm{W}$ & + & + & + & $\mathrm{ND}$ & $\mathrm{W}$ & + \\
\hline Maltose & + & + & + & - & + & + & + \\
\hline Mannitol & - & - & + & + & $\mathrm{ND}$ & + & + \\
\hline D-Mannose & + & + & + & - & + & + & + \\
\hline Melezitose & - & + & - & + & $\mathrm{ND}$ & - & - \\
\hline Raffinose & + & + & + & - & $\mathrm{ND}$ & - & + \\
\hline Rhamnose & - & + & + & + & + & - & + \\
\hline Ribose & - & + & + & + & + & + & $\mathrm{w}$ \\
\hline Sucrose & + & $\mathrm{W}$ & - & + & + & + & + \\
\hline Salicin & + & + & + & - & + & + & + \\
\hline Sorbitol & - & - & - & + & + & $\mathrm{W}$ & - \\
\hline L-Sorbose & - & $\mathrm{W}$ & - & + & $\mathrm{ND}$ & $\mathrm{w}$ & - \\
\hline Starch & + & + & + & - & $\mathrm{ND}$ & + & + \\
\hline \multicolumn{8}{|l|}{ Growth at/with: } \\
\hline $37^{\circ} \mathrm{C}$ & + & + & + & + & ND & - & + \\
\hline $9 \%(w / v) \mathrm{NaCl}$ & + & - & + & - & ND & - & + \\
\hline
\end{tabular}

${ }^{\star} \mathrm{C}$, Cream; LY, light yellow; WH, white; $\mathrm{Y}$, yellow; YW, yellowish white.

(Sherlock version 6.1; MIDI database TSBA6). Determination of the DNA G $+C$ content was performed according to Mesbah et al. (1989).

Whole-cell hydrolysates of strain YIM $61515^{\mathrm{T}}$ contained galactose and glucose. The peptidoglycan hydrolysate contained 
Table 2. Differential chemotaxonomic characteristics of strain YIM $61515^{\top}$ and type strains of species of the genus Promicromonospora

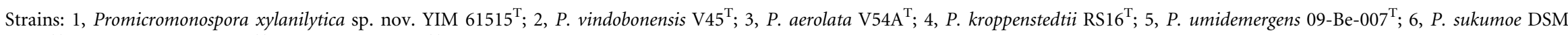

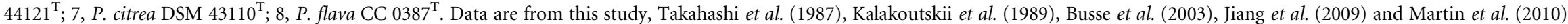

\begin{tabular}{|c|c|c|c|c|c|c|c|c|}
\hline Characteristic & 1 & 2 & 3 & 4 & 5 & 6 & 7 & 8 \\
\hline \multicolumn{9}{|l|}{ Menaquinones (\%) } \\
\hline MK-9 $\left(\mathrm{H}_{8}\right)$ & 3 & - & - & - & - & - & $+^{*}$ & - \\
\hline MK-9 $\left(\mathrm{H}_{6}\right)$ & 46 & 4 & - & 15 & 48 & + & $+^{*}$ & - \\
\hline MK-9 $\left(\mathrm{H}_{4}\right)$ & 29 & 92 & 93 & 64 & 36 & + & $+^{*}$ & 86 \\
\hline MK-9 $\left(\mathrm{H}_{2}\right)$ & 3 & 4 & 7 & 2 & 2 & + & $+^{*}$ & 4.8 \\
\hline MK-9 $\left(\mathrm{H}_{0}\right)$ & - & - & - & - & - & - & $+^{*}$ & 2.64 \\
\hline MK-8 $\left(\mathrm{H}_{4}\right)$ & 19 & - & - & 10 & 6 & - & - & 6.65 \\
\hline Polar lipids $†$ & $\begin{array}{c}\text { DPG, PG, PI, } \\
\text { PL, GL }\end{array}$ & $\begin{array}{l}\text { DPG, PG, GL, } \\
\text { PGL, PL }\end{array}$ & $\begin{array}{l}\text { DPG, PG, two } \\
\text { GLs, PGL, PL }\end{array}$ & $\begin{array}{l}\text { DPG, PG, PI, } \\
\text { GL, PGL }\end{array}$ & $\begin{array}{l}\text { DPG, PG, PI, } \\
\text { PL, three GLs }\end{array}$ & DPG, PI & $\begin{array}{l}\text { PG, PI, a } \\
\text { glucosamine } \\
\text { phospholipid }\end{array}$ & $\begin{array}{c}\text { DPG, PG, } \\
\text { PL, GL }\end{array}$ \\
\hline $\begin{array}{l}\text { Cell-wall amino acids } \\
\text { and type } \ddagger\end{array}$ & $\begin{array}{c}\mathrm{Ala} / \mathrm{Glu} / \mathrm{Lys} \\
(1.90: 1.64: 1.0), \\
\mathrm{A} 4 \alpha\end{array}$ & $\begin{array}{c}\mathrm{Glu} / \mathrm{Gly} / \mathrm{Ala} / \mathrm{Lys} \\
(0.98: 0.69: 2.88: 1.0), \\
\mathrm{A} 3 \alpha\end{array}$ & $\begin{array}{c}\text { Glu/Gly/Ala/Lys } \\
(1.05: 0.43: 3.4: 1.0), \\
\text { A3 } \alpha\end{array}$ & $\begin{array}{c}\text { Ala/Glu/Lys } \\
(2.3: 2.0: 1.0), \\
\text { A } 4 \alpha\end{array}$ & Lys (Glu, Ala) & Lys, A3 $\alpha$ & Lys/Ala, A3 $\alpha$ & Lys (Ala) \\
\hline Cell-wall sugars $\$$ & Gal, Glcll & Rha, Gal, Glc & Rha, Gal, Glc & Rha, Gal & Rha, Gal, Glcll & Rha, Glc, Ribll & Gal & $\begin{array}{l}\text { Rha, Gal, } \\
\text { Glc, Ribll }\end{array}$ \\
\hline
\end{tabular}

${ }^{*}$ MK-9 (hydrogenation was not specified).

$\nmid$ DPG, Diphosphatidylglycerol; GL, unknown glycolipid; PG, phosphatidylglycerol; PGL, unknown phosphoglycolipid; PI, phosphatidylinositol; PL, unknown phospholipid. \$Amino acids in parentheses are minor components.

$\S$ Gal, Galactose; Glc, glucose; Rha, rhamnose; Rib, ribose.

IIWhole-cell sugars. 
alanine, glutamic acid and lysine (1.90:1.64:1.0). The predominant menaquinones were $\mathrm{MK}-9\left(\mathrm{H}_{6}\right)(46 \%)$ and MK-9 $\left(\mathrm{H}_{4}\right)(29 \%)$. Minor amounts of MK-8( $\left.\mathrm{H}_{4}\right)(19 \%)$, MK-9 $\left(\mathrm{H}_{2}\right)(3 \%)$ and MK-9 $\left(\mathrm{H}_{8}\right)(3 \%)$ were also detected. Menaquinone MK-8( $\left.\mathrm{H}_{4}\right)$ has also been found in $P$. umidemergens, $P$. kroppenstedtii and $P$. flava but not in the other four species of the genus Promicromonospora. The phospholipid profile comprised diphosphatidylglycerol, phosphatidylglycerol, phosphatidylinositol, an unidentified phospholipid and an unknown glycolipid (Supplementary Fig. S2, available in IJSEM Online). The major fatty acids were anteiso- $\mathrm{C}_{15: 0}(64.80 \%)$ and iso- $\mathrm{C}_{15: 0}(13.86 \%)$ (Supplementary Table S1, available in IJSEM Online), which were similar to those obtained by Martin et al. (2010) for the type strains of other members of the genus Promicromonospora. The DNA G + C content of strain YIM $61515^{\mathrm{T}}$ was $70.4 \mathrm{~mol} \%$. Strain YIM $61515^{\mathrm{T}}$ could be differentiated from the type strains of other members of the genus Promicromonospora by a range of chemotaxonomic characteristics (Table 2).

For 16S rRNA gene sequence analysis, extraction and amplification of genomic DNA was carried out as described previously (Li et al., 2007). An almost-complete 16S rRNA gene sequence (1437 bp) was aligned with selected sequences obtained from public databases using CLUSTAL $\mathrm{X}$ version 1.8 (Thompson et al., 1997). Neighbour-joining (Saitou \& Nei, 1987) and maximum-parsimony (Kluge \& Farris, 1969) trees were constructed using MEGA version 3.1 (Kumar et al., 2004). To evaluate the stability of the trees, bootstrap analysis was performed using a consensus tree based on 1000 randomly generated trees (Felsenstein, 1985). DNA-DNA hybridization was performed according to the fluorometric micro-well method (Ezaki et al., 1989; He et al., 2005).
Phylogenetic analysis based on 16S rRNA gene sequences showed that strain YIM $61515^{\mathrm{T}}$ was affiliated with the genus Promicromonospora. Strain YIM $61515^{\mathrm{T}}$ was most closely related to $P$. aerolata V54A $\mathrm{A}^{\mathrm{T}}$ and $P$. vindobonensis $\mathrm{V} 45^{\mathrm{T}}(99.4$ and $99.1 \% 16 \mathrm{~S}$ rRNA gene sequence similarity, respectively). Lower levels of $16 \mathrm{~S}$ rRNA gene sequence similarity were observed between strain YIM $61515^{\mathrm{T}}$ and the other type strains of recognized species of the genus Promicromonospora: $98.4 \%$ with P. kroppenstedtii $\mathrm{RS}^{\mathrm{T}} 6^{\mathrm{T}}$, $98.3 \%$ with $P$. umidemergens $09-\mathrm{Be}-007^{\mathrm{T}}, 98.1 \%$ with $P$. sukumoe DSM $44121^{\mathrm{T}}$ and $P$. citrea DSM $43110^{\mathrm{T}}$, and $96.3 \%$ with $P$. flava CC $0387^{\mathrm{T}}$. In an earlier study, Busse et al. (2003) proposed that isolates of the genus Promicromonospora that show $\leqslant 98.6 \% 16 \mathrm{~S}$ rRNA gene sequence similarity with recognized members of the genus probably represent novel species; the $16 \mathrm{~S}$ rRNA gene sequence similarities between strain YIM $61515^{\mathrm{T}}$ and the less closely related members of the genus Promicromonospora (96.3$98.4 \%$ ) were slightly lower than this value. In the neighbour-joining phylogenetic tree (Fig. 1), strain YIM $61515^{\mathrm{T}}$ formed an independent lineage in a cluster containing $P$. aerolata $\mathrm{V} 54 \mathrm{~A}^{\mathrm{T}}, P$. vindobonensis $\mathrm{V} 45^{\mathrm{T}}$ and $P$. umidemergens $09-\mathrm{Be}-007^{\mathrm{T}}$, which was supported by a high bootstrap value. This relationship was also evident in the $16 \mathrm{~S}$ rRNA gene sequence dendrogram generated with the maximum-parsimony algorithm. In view of this, DNADNA hybridization was performed only between strain YIM $61515^{\mathrm{T}}$ and members of the genus Promicromonospora with which the isolate exhibited $\geqslant 98.4 \%$ 16S rRNA gene sequence similarity. DNA-DNA relatedness values between strain YIM $61515^{\mathrm{T}}$ and $P$. vindobonensis $\mathrm{V} 45^{\mathrm{T}}, P$. aerolata V54A ${ }^{\mathrm{T}}$ and P. kroppenstedtii $\mathrm{RS} 6^{\mathrm{T}}$ were $45.1 \pm 3.3,43 \pm 2.1$ and $35.1 \pm 1.7 \%$, respectively. These values were well below the $70 \%$ cut-off value recommended for the circumscription of bacterial genomic species (Wayne et al., 1987),

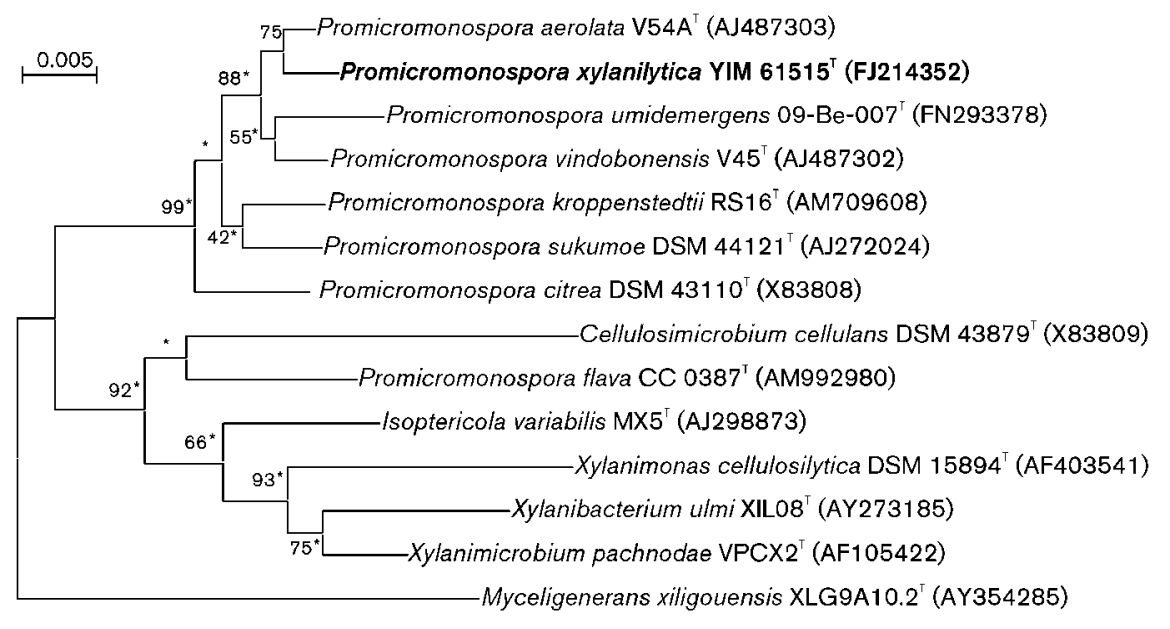

Fig. 1. Neighbour-joining phylogenetic tree based on 16S rRNA gene sequences (1437 nt), showing the relationships between strain YIM $61515^{\mathrm{T}}$ and members of the genus Promicromonospora and the family Promicromonosporaceae. Bootstrap values $(>50 \%)$ based on 1000 replications are shown at branch nodes. Asterisks indicate that the corresponding nodes were also recovered in the tree generated with the maximum-parsimony method. Bar, 0.005 substitutions per nucleotide position. 
indicating that strain YIM $61515^{\mathrm{T}}$ represents a novel species of the genus Promicromonospora.

On the basis of the morphological, chemotaxonomic, phenotypic and genetic characteristics, it is evident that strain YIM $61515^{\mathrm{T}}$ should be assigned to a novel species in the genus Promicromonospora, for which the name Promicromonospora xylanilytica sp. nov. is proposed.

\section{Description of Promicromonospora xylanilytica sp. nov.}

Promicromonospora xylanilytica [xy.la.ni.ly'ti.ca. N.L. n. xylanum xylan, a plant polymer; N.L. adj. lyticus - $a-u m$ (from Gr. adj. lutikos - $\hat{e}$-on) able to loose, able to dissolve; N.L. fem. adj. xylanilytica xylan-dissolving].

Gram-positive and aerobic. Forms white to yellowish white colonies with characteristic wrinkly surfaces. No aerial mycelium is produced. Substrate mycelia develop well and fragment into non-motile, coccoid, Y-shaped, V-shaped or curved bacillary elements. Grows well on ISP 2, ISP 3, ISP 4, ISP 5 and nutrient agar. Grows at $10-37{ }^{\circ} \mathrm{C}$ (optimum $28{ }^{\circ} \mathrm{C}$ ), at pH 6.0-9.0 and with 0-9\% (w/v) NaCl. Positive for catalase and nitrate reduction, but negative for milk coagulation and peptonization, gelatin liquefaction and $\mathrm{H}_{2} \mathrm{~S}$ production. The cell-wall peptidoglycan contains alanine, glutamic acid and lysine. Galactose and glucose are present as cell-wall sugars. The predominant menaquinones are MK-9 $\left(\mathrm{H}_{6}\right)$ and MK-9 $\left(\mathrm{H}_{4}\right)$. The phospholipids are diphosphatidylglycerol, phosphatidylglycerol, phosphatidylinositol, an unidentified phospholipid and an unknown glycolipid. The major fatty acids $(>5 \%)$ are anteiso- $\mathrm{C}_{15: 0}$, iso- $\mathrm{C}_{15: 0}$, iso- $\mathrm{C}_{16: 0}$ and anteiso- $\mathrm{C}_{17: 0}$.

The type strain, YIM $61515^{\mathrm{T}}\left(=\right.$ DSM $21603^{\mathrm{T}}=$ CCTCC AA $208046^{\mathrm{T}}$ ), was isolated from surface-sterilized leaves of $M$. austroyunnanensis collected from the tropical rainforest in Xishuangbanna, Yunnan Province, south-west China. The DNA G $+\mathrm{C}$ content of the type strain is $70.4 \mathrm{~mol} \%$.

\section{Acknowledgements}

This research was supported by the National Basic Research Program of China (grant no. 2010CB833801) and a Key Project of the National Natural Science Foundation of China (grant no. U0932601). The authors are grateful to Dr Paul R. Meyers for his valuable comments on the manuscript.

\section{References}

Alonso-Vega, P., Santamaría, R. I., Martínez-Molina, E. \& Trujillo, M. E. (2008). Promicromonospora kroppenstedtii sp. nov., isolated from sandy soil. Int J Syst Evol Microbiol 58, 1476-1481.

Busse, H.-J., Zlamala, C., Buczolits, S., Lubitz, W., Kämpfer, P. \& Takeuchi, M. (2003). Promicromonospora vindobonensis sp. nov. and Promicromonospora aerolata sp. nov., isolated from the air in the medieval 'Virgilkapelle' in Vienna. Int J Syst Evol Microbiol 53, 1503-1507.

Collins, M. D. \& Jones, D. (1980). Lipids in the classification and identification of coryneform bacteria containing peptidoglycan based on 2, 4-diaminobutyric acid. J Appl Bacteriol 48, 459-470.
Ezaki, T., Hashimoto, Y. \& Yabuuchi, E. (1989). Fluorometric deoxyribonucleic acid-deoxyribonucleic acid hybridization in microdilution wells as an alternative to membrane filter hybridization in which radioisotopes are used to determine genetic relatedness among bacterial strains. Int J Syst Bacteriol 39, 224-229.

Felsenstein, J. (1985). Confidence limits on phylogenies: an approach using the bootstrap. Evolution 39, 783-789.

Gordon, R. E., Barnett, D. A., Handerhan, J. E. \& Pang, C. H. N. (1974). Nocardia coeliaca, Nocardia autotrophica, and the nocardin strain. Int J Syst Bacteriol 24, 54-63.

Groth, I., Schumann, P., Rainey, F. A., Martin, K., Schuetze, B. \& Augsten, K. (1997). Demetria terragena gen. nov., sp. nov., a new genus of actinomycetes isolated from compost soil. Int J Syst Bacteriol 47, 1129-1133.

Hasegawa, T., Takizawa, M. \& Tanida, S. (1983). A rapid analysis for chemical grouping of aerobic actinomycetes. J Gen Microbiol 29, 319-322.

He, L., Li, W., Huang, Y., Wang, L., Liu, Z., Lanoot, B., Vancanneyt, M. \& Swings, J. (2005). Streptomyces jietaisiensis sp. nov., isolated from soil in northern China. Int J Syst Evol Microbiol 55, 19391944.

Jiang, L., Li, M., Li, W., Cui, X., Xu, L. \& Jiang, C. (2001). [Study on the application of quantitative analysis of cell-wall amino acids in actinomycetes classification]. Wei Sheng Wu Xue Bao 41, 270-277 (in Chinese).

Jiang, Y., Wiese, J., Cao, Y.-R., Xu, L.-H., Imhoff, J. F. \& Jiang, C.-L. (2009). Promicromonospora flava sp. nov., isolated from sediment of the Baltic Sea. Int J Syst Evol Microbiol 59, 1599-1602.

Kalakoutskii, L. V., Agre, N. S., Prauser, H. \& Evtushenko, L. I. (1989). Genus Promicromonospora Krasil'nikov, Kalakoutskii and Kirillova 1961a, $107^{\mathrm{AL}}$. In Bergey's Manual of Systematic Bacteriology, vol. 4, pp. 2392-2395. Edited by S. T. Williams, M. E. Sharpe \& J. G. Holt. Baltimore: Williams \& Wilkins.

Kelly, K. L. (1964). Inter-Society Color Council - National Bureau of Standards Color Name Charts Illustrated with Centroid Colors. Washington, DC: US Government Printing Office.

Kluge, A. G. \& Farris, J. S. (1969). Quantitative phyletics and the evolution of anurans. Syst Zool 18, 1-32.

Krasil'nikov, N. A., Kalakoutskii, L. V. \& Kirillova, N. F. (1961). A new genus of Actinomycetales, Promicromonospora gen. nov. Bull Acad Sci USSR Ser Biol 1, 107-112.

Kumar, S., Tamura, K. \& Nei, M. (2004). MEGA3: integrated software for Molecular Evolutionary Genetics Analysis and sequence alignment. Brief Bioinform 5, 150-163.

Lechevalier, M. P. \& Lechevalier, H. A. (1980). The chemotaxonomy of actinomycetes. In Actinomycete Taxonomy, pp. 227-291. Edited by A. Dietz \& J. Thayer. Arlington, VA: Society for Industrial Microbiology.

Li, W.-J., Xu, P., Schumann, P., Zhang, Y.-Q., Pukall, R., Xu, L.-H., Stackebrandt, E. \& Jiang, C.-L. (2007). Georgenia ruanii sp. nov., a novel actinobacterium isolated from forest soil in Yunnan (China), and emended description of the genus Georgenia. Int J Syst Evol Microbiol 57, 1424-1428.

Martin, K., Schäfer, J. \& Kämpfer, P. (2010). Promicromonospora umidemergens sp. nov., isolated from moisture from indoor wall material. Int J Syst Evol Microbiol 60, 537-541.

Mesbah, M., Premachandran, U. \& Whitman, W. B. (1989). Precise measurement of the $\mathrm{G}+\mathrm{C}$ content of deoxyribonucleic acid by highperformance liquid chromatography. Int J Syst Bacteriol 39, 159-167.

Minnikin, D. E., Collins, M. D. \& Goodfellow, M. (1979). Fatty acid and polar lipid composition in the classification of Cellulomonas, Oerskovia and related taxa. J Appl Bacteriol 47, 87-95. 
Qin, S., Wang, H.-B., Chen, H.-H., Zhang, Y.-O., Jiang, C.-L., Xu, L.-H. \& Li, W.-J. (2008). Glycomyces endophyticus sp. nov., an endophytic actinomycete isolated from the root of Carex baccans Nees. Int J Syst Evol Microbiol 58, 2525-2528.

Qin, S., Li, J., Chen, H. H., Zhao, G. Z., Zhu, W. Y., Jiang, C. L., $\mathrm{Xu}, \mathrm{L}$. H. \& Li, W. J. (2009). Isolation, diversity, and antimicrobial activity of rare actinobacteria from medicinal plants of tropical rain forests in Xishuangbanna, China. Appl Environ Microbiol 75, 61766186.

Saitou, N. \& Nei, M. (1987). The neighbor-joining method: a new method for reconstructing phylogenetic trees. Mol Biol Evol 4, 406425.

Shirling, E. B. \& Gottlieb, D. (1966). Methods for characterization of Streptomyces species. Int J Syst Bacteriol 16, 313-340.
Takahashi, Y., Tanaka, Y., Iwai, Y. \& Omura, S. (1987). Promicromonospora sukumoe sp. nov., a new species of the Actinomycetales. J Gen Appl Microbiol 33, 507-519.

Thompson, J. D., Gibson, T. J., Plewniak, F., Jeanmougin, F. \& Higgins, D. G. (1997). The CLUSTAL_X windows interface: flexible strategies for multiple sequence alignment aided by quality analysis tools. Nucleic Acids Res 25, 4876-4882.

Waksman, S. A. (1967). The Actinomycetes. A Summary of Current Knowledge. New York: Ronald Press.

Wayne, L. G., Brenner, D. J., Colwell, R. R., Grimont, P. A. D., Kandler, O., Krichevsky, M. I., Moore, L. H., Moore, W. E. C., Murray, R. G. E. \& other authors (1987). International Committee on Systematic Bacteriology. Report of the ad hoc committee on reconciliation of approaches to bacterial systematics. Int J Syst Bacteriol 37, 463-464. 